Témoigner Témoigner. Entre histoire et mémoire

Getuigen Revue pluridisciplinaire de la Fondation Auschwitz

$119 \mid 2014$

II y a 70 ans, Auschwitz. Retour sur Primo Levi

\title{
Boris Pahor, Quand Ulysse revient à Trieste
}

\section{Anne Roche}

Traducteur : Katrien Vandenberghe

\section{(2) OpenEdition}

Journals

\section{Édition électronique}

URL : http://journals.openedition.org/temoigner/1640

DOI : $10.4000 /$ temoigner. 1640

ISSN : 2506-6390

Éditeur :

Éditions du Centre d'études et de documentation Mémoire d'Auschwitz, Éditions Kimé

Édition imprimée

Date de publication : 31 décembre 2014

Pagination : 201

ISBN : 978-2-84174-688-0

ISSN : 2031-4183

Référence électronique

Anne Roche, "Boris Pahor, Quand Ulysse revient à Trieste », Témoigner. Entre histoire et mémoire

[Online], 119 | 2014, Online op 01 janvier 2016, geraadpleegd op 23 octobre 2020. URL : http:// journals.openedition.org/temoigner/1640; DOI : https://doi.org/10.4000/temoigner.1640

Tous droits réservés 


\section{Boekenplank}

\section{GOEBBELS, EEN BIOGRAFIE}

\author{
Peter Longerich \\ Amsterdam: De Bezige Bij, 2012, 736 p.
}

'Wij Duitsers weten misschien niet hoe we moeten leven. Maar in het sterven zijn we buitengewoon.'

Goebbels, 1933.

$\mathrm{D}$ e veelschrijver Goebbels begon te schrijven toen hij zich als narcistische adolescent Schiller waande. In 1924 noemt hij zich een 'Duits communist' en heel zijn leven zal hij zich voor een socialist houden, terwijl hij tegelijk, na een paar snel vergeten aarzelingen, de voordelen van de macht aanvaardt: auto's, paleizen, schepen. Hij is hevig gekant tegen het christendom en verwacht dat de priesters zullen worden uitgeroeid - het scheelt trouwens niet veel of hij vindt 'de nationaalsocialisten de enige echte christenen'. Maar hij is zich bewust van de kracht van de kerken en huwt volgens religieus gebruik, betaalt kerkbelasting en verzet zich tegen Adolf Wagner, de Gauleitervan München-Oberbayern die het kruisbeeld van de schoolmuren wil laten halen. Maar de overtuigingen van Goebbels doen er niet toe. Hij is bereid om ze op te geven om de persoon te behagen aan wie hij zijn leven wenst te wijden. Goebbels is volledig in de ban van Hitler. Zijn ontmoeting met de man die hij met Christus vergelijkt, is een goddelijk teken. Voor hem vat hij een uitdrukkelijk religieuze, ja zelfs amoureuze passie op. Hitler maakt gebruik van die afhankelijkheid: hij komt tussen in Goebbels' privéleven en geeft hem raad over de vraag of hij moet trouwen en of hij al dan niet moet scheiden. De relatie tussen Hitler en Magda, de vrouw van zijn minister van 'volksopvoeding en propaganda', is bijzonder dubbelzinnig en als Longerich het heeft over de bezoeken die Goebbels' vrouw in haar eentje aan de Kanselarij brengt, spreekt hij zelfs van een 'mariage à trois'. Hoe dan ook is Hitler kind aan huis bij de heer en mevrouw Goebbels, zijn vertrouwelingen. Als Goebbels ‘ongelukkig genoeg’ als eerste kind een dochter krijgt, troost Hitler hem: 'Een jongen had het niet kunnen hebben om met zijn vader te worden vergeleken.' Maar Hitler zal van het meisje houden 'als van zijn eigen kind'.

Ondanks de nauwe band tussen Goebbels en zijn Führer neemt die laatste geen enkele grote politieke beslissing in overleg met hem. Vanaf de machtsgreep wordt hij bijna altijd voor de voldongen feiten geplaatst, maar moet er wel de gepaste propaganda over voeren. Hij wordt ver gehouden van de beslissingen over een Spaanse interventie. Hij wordt niet op de hoogte gebracht van de aanval tegen Polen en al evenmin van die tegen de Sovjet-Unie, waardoor hij volledig verrast is, en hij zou laattijdig zijn ingelicht over het begin van het euthanasiebeleid. Hij wordt niet geïnformeerd over het einde van de slag om Koersk en Hitler doet er lang over om hem de waarheid te vertellen over de landing in Normandië. En de Führer is zelfs niet overtuigd van Goebbels' concept van de 'totale oorlog'. Toch mogen we er, op basis van diens notitieboekjes, volgens Longerich van uitgaan dat Goebbels op de hoogte is van de slachtingen die van in het begin van de oorlog in het oosten plaatsvinden.

In elk geval slaagt hij er, ondanks zijn pogingen om alles te controleren en zijn persoonlijke verhouding met de Führer, nooit in om zich op te werpen als de enige baas aangaande opvoeding en propaganda. Otto Dietrich is het hoofd van de persdienst, nochtans een essentieel propagandaonderdeel. Goebbels is evenmin chef van de dienst buitenlandse propaganda, die valt onder de bevoegdheden van Joachim von Ribbentrop, de minister van Buitenlandse Zaken. En bij het uiteenzetten van de doctrine van het nationaalsocialisme tot lering van de massa's moet hij rekening houden met de invloed van Alfred Rosenberg.

In zijn boek over Himmler had Longerich in een korte paragraaf gesteld dat de Reichsführer niet zeer hoog zou zijn gerangschikt als men de 'raciale criteria' van de SS op hem had toegepast. Van Goebbels, een van die mannen die de waarde van anderen alleen bepaalden op basis van hun uiterlijk, hun gestalte, de vorm van hun schedel en de kleur van hun haar, vermeldt Longerich alleen zijn 'tengere gestalte'. Je begrijpt meteen waarom Goebbels het niet kon vinden met Rosenberg, die de lof zong van de grote, blonde, noordse langhoofden.

Hij mag dan zelf niet tot fysiek geweld in staat zijn, hij heeft wel talent voor het geweld van het woord. Hij is vaak te zien tijdens processen, in de Reichstag of in 
het Pruisische parlement, waar hij schreeuwt en tot geweld aanspoort. Hij zet aan tot de 'totale oorlog' en steunt het lynchen van geallieerde piloten die op het grondgebied van het Reich worden neergeschoten. En vooral hij, meer nog dan Hitler zelf, zet aan tot geweld tegen de Joden, van de Kristalnacht tot de deportaties. Hij wil de Joden een kenteken geven en is geobsedeerd door het idee dat alle Joden uit Berlijn moeten vertrekken. Hij vindt dat ze als oorlogshitsers 'op de een of andere manier' moeten worden uitgeroeid. Hun 'lot is hard maar verdiend', zelfs al is hun straf 'barbaars'. Op 10 oktober 1941 heeft hij het in een toespraak over 'de vernietiging van de Joden'. Maar hij begrijpt ook dat de nationaalsocialisten 'hun schepen hebben verbrand' en dat de medewerking van de Hongaren aan de anti-Joodse nazipolitiek het voor hen onmogelijk maakt om terug te krabbelen en hen met het lot van het Reich verbindt.

De passages die Longerich wijdt aan de cinema, het krachtigste propagandamiddel, ontgoochelen. Hij laat zien dat Goebbels vrij welwillend staat tegenover Fritz Lang, maar spreekt zijn twijfels uit over het algemeen aanvaarde verslag dat Lang over zijn ontmoeting met Goebbels uitbrengt. Die laatste kan het niet vinden met Leni Riefenstahl. Hij vindt haar te warrig en, hoe kan het ook anders, hysterisch. Hij geeft toe dat ze talent heeft, maar 'Was het maar een man!' Dus wordt Triumph des Willens gefinancierd door de partij en niet door het ministerie van Propaganda. Longerich had er kunnen aan toevoegen dat Bormann, met geld van Hitler, de film Tiefland financiert, waarin Leni Riefenstahl een zigeunerdanseres speelt.

Maar in het algemeen erkent Goebbels het falen van de nationaalsocialistische cultuurpolitiek. 'Defilms zijn slecht' en hij geeft ook toe dat de kunst en literatuur ondermaats zijn.

Goebbels is er zich van bewust dat de Berlijners onrustig worden door het oorlogsrisico en hij merkt dat de bevolking negatief reageert op de deportaties. Toch beoordeelt hij minder goed dan de SD (Sicherheitsdienst) hoezeer de Duitse opinie verslechtert over de wending die de oorlog neemt, in het bijzonder de luchtbombardementen. Het imago van Hitler gaat er in zijn eigen land op achteruit, terwijl heel Goebbels' propagandaberustte op het benutten van diens charme. Ondanks de talrijke bezoeken die Goebbels, in tegenstelling tot Hitler, aan de vernielde steden aflegt - waarbij Longerich systematisch het aantal doden vermeldt - slaagt hij er niet in om de opinie te doen omslaan ten voordele van het nationaalsocialisme en de figuur van Hitler. Longerich betwist het imago van Goebbels als een 'virtuoos' van de propaganda.

Het boek van Longerich is een helder, feitelijk en chronologisch werk over de geschiedenis van het nationaalsocialisme, opgedeeld in vrij korte en gemakkelijk leesbare hoofdstukken. De uitgever had het al nuttig geacht om Longerichs biografie van Himmler te presenteren door middel van een reclameslogan op de eerste pagina: 'hoe een gewone man elke dag meer monster werd'. Voor de biografie van Goebbels is het citaat 'de definitieve biografie’ van Die Welt bijzonder ongeschikt, want het woord 'definitief' maakt geen deel uit van het geschiedkundige taalgebruik. Door de publicatie van Himmler in pocketformaat zijn deze bezwaren gelukkig niet van toepassing.

Jean-François Forges

(Vertaling: Gorik de Henau)

\section{SHATTERZONE OF EMPIRES}

Omer Bartov \& Eric D. Weitz (eds.)

Bloomington: Indiana University Press, 2013, 543 p.

$\mathrm{T}$ he title Shatterzone of Empires announces from the start the approach Omer Bartov and Eric D. Weitz chose. The "shatterzone" of the four empires, which broke up after the First World War into modern nation states, is a notion of space. Spread over a number of scales - empires or States, regions (Galicia, Upper Silesia, Carpathian Ruthenia), towns (Vilnius, Krakow), small towns (Buczacs), the space of the borderlands should be understood according to the various meanings of the term: borderlands, marches, frontier zones. Documenting the ethnic, cultural and religious diversity of these territories as well as the local violence that erupted in the course of the $20^{\text {th }}$ century supposes therefore the inclusion of the findings within this "spatial turn". Since the 1980s, new epistemological frameworks have emerged within humanities generally and more specifically in historiography and history, a discipline which is vastly represented by the contributors to this volume. The idea of a study specifically on borderlands arose some time ago already, within 
interdisciplinary works in Europe and in the United States. In France, in 2005, the idea namely sparked an edition of Cultures d'Europe centrale, La destruction des confins [Cultures of Central Europe, The destructions of borders] (followed up by two other articles, Voyage dans les confins and Le Mythe des confins, published respectively in 2003 and 2004), under the supervision of Delpine Bechtel and Xavier Galmiche. In regards to this pioneering initiative, the volume we presently have in our hands widens the question. Indeed, the integration of the Ottoman Empire within the shatterzone was a way of constructing a diachronic and comparative vision of the genocidal violence of the $20^{\text {th }}$ century. If the present book surprisingly makes no mention of this work (whereas Omer Bartov was one of its contributors), the writers however take a critical stance from the very first pages of the introduction on another study of the violence which adopts a spatial approach: Bloodlands, Europe between Hitler and Stalin by Timothy Snyder, published in 2010 by Basic Books (New York). Indeed, the violence within European borderlands cannot only be attributed to the conflict between the USSR and Nazi Germany, for it had been simmering beforehand in these regimes, often caused by internal situations rather than imposed from the outside. Unlike Bloodlands, Shatterzone of Empires therefore proposes a detailed exploration of imaginary and symbolic constructions as well as political and economic configurations.

This exploration of the borderlands also takes into consideration another historiographic turn, namely, the possibility of including sources that used to be considered as peripheral, such as speeches, perceptions, imaginaries, subjective memories, in short, elements that were situated in the margins of great narratives. The periphery is here much more than merely a notion of space, it is also to be understood epistemologically. It is about rethinking, within the concerned geographical and political space and similarly to the hierarchy of knowledge (between great History and microhistory, for example), the relation between centre and periphery. The borderlands, which even the most centralized or dictatorial powers do not totally control, are thus a metaphor for new approaches. The legitimization of tools which historians are traditionally suspicious of, is nevertheless subjected to critical reflection. Omer Bartov's article, which concludes the fourth part on the violences in the borderlands, is thus based on personal stories relating a local genocide at Buczacz, in Eastern Galicia, between 1941-1944. As a result, the consideration of personal testimonies seems arguably necessary to write a "three-dimensional" history, using tools derived from microhistory and the history of daily-life, as well as being attentive to the complexity and contradictions which disappear as soon as one privileges a more global analysis. The specific study of these documents allows a view into the communities as well as jumps into the past, often overlooked by historians of violences. However, it is not about yielding to the illusion of grasping the logic behind the violences "at the source". A diachronic study of the borderlands from the dawn of nationalism at the end of the $18^{\text {th }}$ century until today, supposes a dynamic approach to social processes. One cannot escape the theoretical danger of researching the origin, but also an interpretation of the violences as a simple exacerbation of the exclusion or segregation practices established previously. Suffice to say that everything is done so as to avoid a mythical reading of the borderlands and their destruction.

As zones of freedom within empires, the peripheries easily became places of instability during their fragmentation. Furthermore, the transition to Nation States is questioned throughout this volume as an emerging mode of a modernity which, by deeply modifying social configurations, destroys the balance of complex neighbour relationships. The construction of a problematic figure of the other, which progressively became an object of exclusion or even of extermination, is analysed in the first part of the book (article by Larry Wolf) through the prism of imperial imaginaries shaped by identity, from travel narratives in which we see Poles through the eyes of a German (Fichte travelling in 1791), Germans through the eyes of a Pole at the same period (Niemcewicz). These constructions were backed up by myths present in speeches and political practices. The Eastern borderlands of Germany were perceived for example as an entrance into a menacing territory and a wild land which needed civilizing (Gregor Thum). However, prior to becoming a hostile figure, the other could have an "invisible neighbour" like the Jews at Vilna-Wilno-Vilnius (Theodore R. Weeks) where, like in every multicultural city, coexistence did not necessarily only rest upon tolerance and mutual interest, but also on populations overlooking their otherness, as each considered the space as their own. In this same section, Dan Diner examines the situation of Jews "between empire and nation state" in the middle of the $18^{\text {th }}$ century and concludes with their 
maladjustment to the new model. If, individually, the Jews were important actors of European modernity, as a community however, they followed pre-modern patterns. Confronted to identity aporias with a new conception of citizenship and an emerging national identity, these communities were swept toward disaster, the Holocaust being the ultimate manifestation.

A multitude of factors, which can mainly be defined as the advent of modernity, is necessary to understand what triggered the beginning of violence. In the second part of the book, dedicated to imperial spaces, Gary B. Cohen, as well as Peter M. Judson, propose, following the Austro-Hungarian Empire example, to concentrate not on the nature of the nationalist movements and the decline of the empires that do not satisfy them, but rather to look at the relation between the State and society. The way in which the population in the borderlands entered into modernity is rethought generally. Frithjob Benjamin Schenk shows namely, by analyzing travel narratives, how the railroads, which allowed the population of the Russian Empire to discover the ethnic and religious diversity of the borderlands (the zone of Jewish residency, as it happens), were also a tool in the hands of those who sought to shake the political situation (terrorist groups or perpetrators of pogroms). In theory a factor of social integration, trains were also a factor of violence and of disintegration.

One original component of the book is that imperial ambitions are envisaged from the angle of colonialism. Both the second and third parts of the book are dedicated to the emergence of national speeches in the borderlands, as well as the fourth part, which specifically deals with the question of violence. Reference is made to Turkish colonialism (David Gound), with the extermination of Assyrian, Chaldean and Syrian Christians in the Ottoman Empire. This genocide is not well-known namely because of the difficulty of attributing a common identity to the population which, unlike the Armenians, was outside of the political arena. The subject of Russian colonialism is also broached (Peter Holquist), seen through the violence perpetrated by the army on the Ottoman territory and in North Persia (Urmia and Astarabad). This article is a reminder of the stake Caucasus played in the Russo-Turkish conflict and enlightens Russian military practices: control of the territory, punitive expeditions, massive requisitions, population displacements, practices which were fated to carry on after the revolution with the goal of integrating the zones of influence or of long-standing conflict to the new Soviet State, and then fated to become widespread during the Second World War. Reference is made to German colonialism, finally, which targeted the Ottoman Empire and led to a complicity with Germany in the genocide of the Armenians and Assyrians (Eric D. Weitz). Genocidal practices were incidentally tested by German military on the Herero people and the Namaqua in South-West Africa.

If the First World War offered a particularly rich field of observation for the violence nested in the borderlands, it does not however lie at the origin. Within these European and adjacent spaces, persecutions and deportations had already taken place during the Balkan Wars of 1912-1913. The radicalization of new discourses regarding Muslim Ottoman identity and the exclusion of non-Muslims within the national community which led to the genocide of the Armenians, must be understood as one of their consequences (Eyal Ginio). The emigration of Christian populations (especially Bulgarians) largely encouraged by the government after the defeat, was a step toward the idea of ethnic cleansing. Elke Hartmann shows with the example of the isolated Kurdish and Armenian provinces in Asia Minor how fragmentation and delegation of power within borderlands contributed to the escalation of violence, orchestrated by the States and often carried out by the population. Remaining within the field of the Balkan Wars, we shall address the massacres committed by the Greeks upon Bulgarian civilians (Keith Brown), as well as the anthropological value of the sources which attest to it (letters of soldiers) but are disputed by the Greek authorities.

The perpetuation of the violence from one war to another brought about the pogroms of 1941 (Alexander V. Prusin), perpetrated by Poles and Ukrainians on their Jewish neighbours in Eastern Galicia, as a heritage of the First World War: pogroms and deportations committed by the Russian army in 1914-1915, plundering of abandoned houses by locals. The "Jedwabne syndrome" is considered, here again, through the prism of a modernization that intensified socio-economic and political rivalries.

The execution of prisoners by the NKDV in Ukraine at the time of the Red Army's retreat in 1941 served, as we know, as a pretext to spark anti-Jew pogroms. Drawing on the example of Krakivski visti, a Ukrainian daily newspaper published in Krakow, John-Paul Himka followed the international media coverage of these crimes in order to show the way in which both 
the victims and the criminals became ethnicized by Nazi and Ukrainian propaganda. This article is echoed by the one by Kai Struve, in the final part of the book, which deals with rites, symbolism and identity, and proposes a reading of Stalinist and Nazi violence based on the symbolic and identity investment of Galician space as well as the social changes brought with the Russian revolution. As a result, Jews, who previously only had limited rights, gained access to the structures of the new power.

The final part of the book raises questions which had remained in the margins of the four previous parts, such as the coastal borders in the East Adriatic (Pamela Ballinger); the Ukrainian and Jewish artistic revival in the borderlands brought by the Russian revolution and presenting a surprising synthesis of national and international aspirations. There is also the study of an exceptional case: the non-violent interethnic coexistence in Carpathian Ruthenia (Paul Robert Magosci). Finally, the last contribution, by Philipp Ther, is dedicated to regionalisms up until today. The example of Upper Silesia, germanized under German domination, polonized by force after the war, offers the opportunity to think of the regions not as places with defined borders, but as objects of discourses, therefore symbolic constructions in perpetual transformation.

We would have wished to find, within this overview, a study of the Sovietization of the borderlands that followed the divide of Poland and Romania between the USSR and Nazi Germany in 1939 and which continued after the war. There is particularly lacking a study on Bessarabia, partially annexed by the USSR after the German-Soviet Pact, only to be later recaptured by Romania allied to Nazi Germany, of which one of its territories, Transnistria, became a zone of deportation and of extermination.

Finally, if centripetal logic or, on the contrary, unifying logic, is mentioned through the notion of Pan-Germanism, there is also sadly lacking a study on Pan-Slavism which played an equally important role namely within the Habsburg Empire. The Russian Civil War, and consequently the Polish-Soviet War, both having generated large-scale pogroms, would also be worth including. However, the book does not claim to be exhaustive and above all, it aims to put new approaches into practise. Therefore it is a valuable and timely contribution to the field.

Luba Jurgenson

(Translation: Sarah Voke)

\section{L'IRRÉPARABLE. ITINÉRAIRES D'ARTISTES ET D'AMATEURS D'ART JUIFS, RÉFUGIÉS DU 'TROISIËME REICH' EN FRANCE}

Anne Grynberg \& Johanna Linsler (red.)

Veröffentlichungen der Koordinierungsstelle Magdeburg, Band 9, bearb. v. Andrea Baresel-Brand, Magdeburg 2012, $454 \mathrm{p}$.

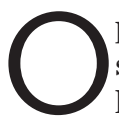
p het eerste gezicht lijkt 'Irréparable' (onherstelbaar) een ongepaste term als het gaat over het lot van geplunderde en geroofde kunstwerken tijdens de Tweede Wereldoorlog. Zo hebben de omvergeworpen kisten met schilderijen aan het slot van The Train - de in 1964 uitgekomen film van John Frankenheimer - iets bespottelijks vergeleken met de lichamen van vermoorde gijzelaars. Bespottelijk en bijna obsceen lijkt het, om kunstwerken te redden in plaats van mensenlevens.

Toch is dit boek een opmerkelijke oefening: de auteurs bestudeerden de levensweg van Joodse kunstenaars en kunstliefhebbers die tijdens de oorlog naar Frankrijk zijn uitgeweken, en konden zo het lot van deze mensen verbinden met dat van de kunst die zij hebben beoefend of verzameld. Toen Goebbels op 22 september 1933 de Rijkskultuurkamer oprichtte, twee jaar voor de Neurenbergse wetten, werden de zeven kunstenaars en verzamelaars uit de Duitse kunstwereld geweerd en gingen in ballingschap. Dat deze kunstenaars uitweken naar Frankrijk, meer bepaald naar Parijs, laat zich verklaren door het feit dat zij, met uitzondering van de jonge Horst Rosenthal, er dikwijls al vóór 1914 hadden verbleven en er persoonlijke of professionele banden onderhielden. Het leven van deze zeven kunstenaars legt een stukje van de geschiedenis en van de kunstwereld bloot in het Frankrijk van de jaren dertig. Niet veel later zouden zij die dat nog konden opnieuw in ballingschap gaan, ditmaal naar Noord- en Zuid-Amerika. Hierover schreef Jean-Michel Palmier het verhelderende werk Weimar en exil. Le destin de l'émigration intellectuelle antinazie en Europe et aux États-Unis dat in 1988 voor het eerst werd uitgegeven.

Kunstcriticus en -verzamelaar Paul Westheim, 
van wie Ines Rotermund-Reynard de levensweg schetst, was een van hen. Westheim blijft in Parijs zijn journalistieke activiteiten uitoefenen, voor hij in 1941 naar Mexico emigreert. Dat gebeurde dankzij tussenkomst van het Emergency Rescue Committee, het Amerikaanse Centrum voor Hulpverlening dat in Frankrijk onder leiding stond van journalist Varian Fry. In haar inleiding herinnert Anne Grynberg ons aan zijn sleutelrol. Meesterglazenier en abstract kunstenaar Otto Freundlich (Geneviève Dabien), vriend van Kandinsky aan wie hij de toen nog piepjonge schilder Serge Poliakoff voorstelde, slaagde er echter niet in om te emigreren en kwam in 1943 om in Sobibor. Frankrijk heeft hem niet beschermd. Pablo Picasso, die slechts de huurachterstand van zijn atelier kon betalen, wist tot aan de Bevrijding zijn werken te beschermen. De nazi-ideologen maakten van Freundlichs werken het symbool van de 'ontaarde kunst'. Ze illustreerden de kaft van de tentoonstellingscatalogus Entartete Kunst van München in 1937 met een afbeelding van Grande tête (Grote Kop, ook wel 'Der Neue Mensch' genoemd) die Freundlich in 1912 had gebeeldhouwd; een bewijs dat, in de ogen van de nazi's, de 'ontaarding' van de kunst het gevolg was van diens 'verjoodsing'.

Het onrecht dat Westheim en Freundlich is aangedaan - en met hen zovele andere kunstenaars, onder wie Leo Maillet (Sandra Nagel) of Jesekiel David Kirszenbaum (Johanna Linsler) - als mens én als Jood, is dus ook van toepassing op hun persoonlijke kunstzinnige activiteit. Zij werden in dubbel opzicht vervolgd, niet alleen als Jood maar ook als kunstenaar of kunstcriticus, wat symptomatisch is voor het proces van onteigening dat volgens Raul Hilberg het uitgangspunt heeft gevormd voor de vernietiging.

De werken van andere kunstenaars (zij die niet tot de avant-garde behoorden) werden door de oorlog gedegradeerd van begeerde objecten tot oorlogsbuit. Met de mengeling van dogmatisme en gangsterisme die het uitbuitings- en vernietigingsplan van het Derde Rijk kenmerkte, stortten Hitler, Göring, Goebbels, Rosenberg, Abetz en in hun kielzog honderden Franse en Duitse verzamelaars, kunsthistorici, privédetectives en verklikkers zich vanaf juli 1940 op kunstwerken van Joodse privé-collecties in Frankrijk.

Zoals Michel Rayssac aantoonde in L'Exode des musées en ook Guillaume Fonkenell in Le Louvre pendant la guerre, hadden alleen de conservatoren van Franse publieke collecties de middelen zich te verzetten. Ze konden hun collecties tijdig in veiligheid brengen en vervolgens stap voor stap onderhandelen over het behoud van hun integriteit.

Het optreden van Rose Valland ligt op de grens tussen publieke en privésfeer en kunnen we beschouwen als een verzetsdaad. Valland was in 1940 door de directeur van het Louvre, Jacques Jaujard, aangesteld als attachee Conservering van het depot van het Musée Jeu de Paume, waar de nazi's hun geroofde werken hadden gesorteerd en tijdelijk opgeslagen. In het geheim had ze al die kunstwerken geïnventariseerd en na de oorlog maakte zij deel uit van de Restitutiecommissie (voor claims van kunstroof). 60000 van de 100000 werken die tussen 1940 en 1944 uit Frankrijk waren geroofd, konden op die manier worden teruggevonden en gerepatrieerd.

Bij het lastige onderzoek naar bronnen over dit onderwerp beschikt Anne Liskenne over de bijzonder belangwekkende getuigenis van Rose Valland (in 2014 heruitgegeven door RMN) die Frankenheimer heeft geïnspireerd tot het maken van zijn film The Train (en recent ook George Clooney's The Monuments Men, noot van de vertaler).

In een voetnoot herinnert Anne Liskenne ons eraan dat de term 'plundering' sinds het proefschrift van Gérard Lyon-Caen uit 1945 verwijst naar de daden van diefstal begaan door de Duitsers, terwijl met 'roof' wordt verwezen naar het door de Vichy-regering gevoerde beleid inzake kunstbezit en andere goederen. Dit onderscheid toont aan met welke haast het recht zich het onderwerp heeft toegeëigend. Toch heeft het begrip 'billijkheid' stukje bij beetje de overhand gekregen op dat van 'recht', omdat in sommige gevallen een principe van uitzonderlijkheid geldt, analoog aan dat van toepassing op misdaden tegen de menselijkheid, waardoor de verjaringstermijn vervalt die het recht had ingesteld.

Een begrip als ‘verjaring' duidt er inderdaad op dat het recht als zogenaamd 'instituut' een maat van menselijke tijd induceert en dus een temporaliteit oplegt voor herinnering en vergeten. Het Franse recht, zo schrijft Anne Liskenne, 'bepaalt dat ieder niet geclaimd goed na dertig jaar toekomt aan de instelling of aan de particulier die het in bezit heeft'. 'Maar', zo voegt ze eraan toe, 'de wet werd niet toegepast op die goederen [in casu de kunstwerken] die aan geen enkele verjaringstermijn gebonden zijn en die op ieder moment aan de betrokken families kunnen worden teruggegeven.' (98) In hun voorwoord bij L'Irréparable wijzen Jutta Limbach en Michel Jeannoutot er nogmaals op 
dat ook in Duitsland schadeloosstellingen kunnen worden toegekend buiten een strikt juridisch kader, waarbij zich defacto principes inzake ethiek en moraal in de plaats stellen. Door op deze manier te wijzen op de juridische grenzen van het recht en door aan het recht het monopolie te ontnemen van de afbakening van wat rechtmatig is, laat deze afwijking van de wettelijke verjaringstermijn ruimte voor een alternatieve temporaliteit: die van de herinnering waaraan de maatschappij een gelijkwaardig gezag toekent als aan dat van het recht, een rechtswaarde die niet strikt juridisch is.

Het 'irreparabele' of onherstelbare verwijst juist naar de atemporaliteit van de geleden schade en naar de fundamentele onmacht van het recht om voor herstel te zorgen. Het is aan de geschiedenis, zoals ze in dit boek wordt omschreven en zoals fictie haar zou kunnen verhalen, te beschrijven hoe deze kunstenaars en kunstliefhebbers niet alleen van hun werken en hun kunst werden beroofd, dat wil zeggen van een deel van henzelf, maar vervolgens ook nog eens fysiek werden vervolgd. Deze verhalen zijn als de stukken van een dossier waarover de herinnering, en niet meer het recht, gerechtvaardigd is zich uit te spreken. Die herinnering wordt gesymboliseerd in de Kop van Otto Freundlich die op de kaft van L'Irréparable is afgedrukt, een andere dan de Grote Kop, eentje uit 1925 die in 2010 tijdens opgravingen op een bouwterrein in Berlijn werd aangetroffen (hier rechtop afgebeeld in al zijn onvolledigheid en met een brokstuk van de kop ernaast). En in het licht van de kunstgeschiedenis verzacht deze afbeelding het onrecht dat Grande tête (Grote Kop) uit 1912, in 1937 is aangedaan. I

Paul Bernard-Nouraud

(Vertaling: Macha Snouckaert van Schauburg)

\section{L'ENSEIGNEMENT DE LA TORTURE, RÉFLEXIONS SUR JEAN AMERY}

\author{
Catherine Perret \\ Parijs: Seuil, 2013, 207 p.
}

6 etzt passiert's' : 'nu gaat het gebeuren'. Deze korte maar afgrijselijke zin, uitgesproken door zijn beul, zou Jean Améry (pseudoniem van Hans Mayer) altijd blijven achtervolgen. Vanwege zijn verzetsactiviteiten in België bij het Ősterreichischen Freiheitsfront werd Améry in 1943 door de Gestapo opgepakt, vervolgens gefolterd in Fort Breendonk om daarna naar Auschwitz te worden gedeporteerd vanwege zijn Joodse afkomst. Zo'n twintigjaar na de feiten legt deze 'jood-van-de-catastrofe' (158) in Schuld en boete voorbij, verwerking van een onverwerkt verleden (vertaald uit het Duits door Leonard Nolens, Antwerpen \& Amsterdam: Atlas, 2000) een indrukwekkende getuigenis af, met veel facetten, over zijn conditie als gefolterde en gedeporteerde intellectueel.

Bijna vijftig jaar na de verschijning van deze bundel, die onder intellectuelen sterke reacties uitlokte, komt Catherine Perret terug op Jean Améry's essay met een briljant werk: L'enseignement de la torture: Réflexions sur Jean Améry. In haar boek geeft zij een interessante herinterpretatie van alsook een diepgaande reflectie over de intellectueel en zijn tragische lot (Jean Améry pleegde in 1978 zelfmoord). Het nodigt uit een blik te werpen op dit gefolterde lichaam dat het onze is en op dit 'wij' dat meer dan een halve eeuw later nog steeds weerstand moet bieden. In de marge van de analyse van Améry's tekst wijst Perret erop dat foltering nog altijd een groot actueel probleem is: het is een denkbare methode, een oplossing, ja, in bepaalde gevallen zelfs een noodzaak. En juist hierop levert zij in haar voorwoord felle kritiek. Ze haalt feiten aan die zich hebben voorgedaan aan het begin van deze eeuw, met name de Global War on Terror die president Bush startte na 11 september 2001 en waarbij de staat bijzondere bevoegdheden kreeg.

'[D]e [nazi]-mythe heeft een plaats van handeling: het uitroeiingskamp. Een rite: de foltering. Een totem: de naziheld. En een taboe: het lichaam van de ontaarde Jood.' 
Deze ware ervaring van 'ruïne van lichamen' vormt de essentie van de 'concentratiekampfilosofie'. Folteren wordt een ceremonie. Veel meer dan louter een middel is het een uitgebreid ritueel dat Catherine Perret in haar boek presenteert, met name in het hoofdstuk 'Écrire le cri', 'De schreeuw beschrijven'. De nazitortuur is de 'spirituele essentie van het Derde Rijk' via een soort van zelfontkenning, door de geleidelijke marteling van zijn slachtoffer en dus de vernietiging van (het lichaam van) de Ander, herdefinieert de beul zichzelf. Catherine Perret evoceert de 'moorddadige zelfbevestiging' waarover Jean Améry het heeft, als een complex dat het sadisme van de daad definieert. De nazitortuur kadert dan in een bijzonder zelfverloocheningsproces. Het 'zijn' wordt opnieuw geconfigureerd, 'het woord sein betekent in het Duits zowel er zijn als zijn van', wat een dubbele positie impliceert van het gefolterde wezen in diens relatie met het ' $\mathrm{Ik}$ ' van de beul.

Voor de nazibeul, die streeft naar heroïsche zelfbevestiging, wordt het lichaam binnen het universum van de foltering op een specifieke manier verbeeld. Het lichaam van de Ander wordt het stervende 'Dat', dat zijn 'Ik' opgeeft ten gunste van het 'Ik' van de folteraar. Vervolgens ontstaat het moment dat beide eenheden, folterend lichaam/gefolterd lichaam, diametraal tegenover elkaar komen te staan: het ultieme moment waarop het slachtoffer 'prooi van de dood' wordt (een quasi-dood, waarbij wel het ergste het 'quasi' is). Het slachtoffer is bezield door een plots verlangen te sterven in plaats van te ondergaan, terwijl de beul geen belang meer stelt in dit sterven in zijn onmiddellijke nabijheid, aangezien dit indruist tegen zijn idee van zelfbevestiging.

Catherine Perret herintroduceert het begrip 'slechtheid' (dat al eerder werd gebruikt door Thomas Mann) wanneer ze de nazibeul omschrijft als iemand die 'denkt groot te worden in het dragen van andermans lijden'. Binnen dit ritueel ontstaat een dialectiek van het lijdende lichaam, waarbij zelfbevestiging wordt gevonden bij de aanblik van de lijdende Ander. Dit fenomeen, zo stelt Perret, vinden we terug bij de gladiatoren uit de Oudheid tot in de snuffmovies. Telkens levert het (voyeuristische) kijken naar het lichamelijke lijden van de Ander een ongezonde en sadistische ervaring van zelfbevestiging op. Het lijden van het door de nazi gefolterde lichaam is in feite een soort 'parodie' van de transsubstantiatie, omdat het lichaam van de gefolterde de identiteit van de folteraar transformeert. Het gefolterde lichaam wordt een 'Totalkörper': het is niet meer 'het lichaam van de gefolterde. Het is ons lichaam'. Het lichaam, het vlees, is een fantasme (het gefolterde lichaam zou de personificatie zijn van het fantasme van zelfbevestiging).

Tijdens deze 'folteringsviering' beschouwt het nazisme de Joden als 'Stücke' (stukken). Volgens de nazi-ideologie moeten deze stukken een voor een worden weggenomen - 'de extase van het cijfer is het brandmerk en de vernietiging van de naam'. Het hele systeem van concentratiekampen werd in die geest ingericht: de mensen wordt hun individualiteit ontnomen en worden gereduceerd tot naakte lichamen, hun eigennamen worden vernietigd en vervangen door een nummer, 'de imago's van het Ik worden tenietgedaan door de afschaffing van begrafenisriten' met als bedoeling de identiteit van de persona beetje bij beetje af te breken. Daarbij komt nog de obsessie om de 'Stücke' door elkaar op te stapelen in gaskamers (samenklontering van stervende lichamen), treinen en massagraven, en worden er in de concentratiekampen, waar het lichaam wordt blootgesteld aan extreem lijden, 'personages' gecreeerd: de muzelman bijvoorbeeld (een wandelend lijk, meer dood dan levend, dat ter plekke neervalt om na een ultieme korte stuiptrekking te sterven in de gebedshouding van de moslim of muzelman) of het lid van het Sonderkommando (belast met het 'voorbereiden' van de andere gedeporteerden voor de gaskamer en met het reinigen hiervan na vergassing met Zyklon B).

Het schrijven over foltering is een schrijven over het acme of het hoogtepunt, een ervaring van de schrijfbare schreeuw: de schreeuwvan pijn van het gefolterde lichaam. Het hoogtepunt van dit sadistische ritueel is het ogenblik van de bekentenis, het moment waarop het vlees Woord wordt, ook al is het onzinnig (Améry schrijft zichzelf daden toe die hij niet heeft begaan), het moment waarop een 'schaduw [...] uit het niets ontsnapt' - die schaduw is het Ik. 'Améry's essay voert opnieuw het offer op waarvan hij het voorwerp was.' In zijn tekst lezen we, in de taal van de beul, hoe het Ik uittreedt uit het gefolterde lichaam. Catherine Perret definieert het Zijn volgens een drieledige relatie bestaande uit het Sich (een 'op-zich'), het Selbst (een 'voor-zich') en het der Nächste ('de naaste'): op het hoogtepunt van het folteringsritueel is het de schreeuw die de vernietiging van de naaste - der Nächste - sacraliseert.

De doodskreet van het slachtoffer is een soort ultieme irrintzina: een absolute kreet, waardoor het Ik uit het lichaam wordt gedreven. Om de vernietiging te sacraliseren, moet men deze paroxystische 'superschreeuw' horen. Freud heeft het over de 'oerfunctie 
van de schreeuw bij de ontogenese van het individu'. Deze schreeuw, afkomstig van het 'gillende vlees', is een soort orgasme voor het folterende lichaam en precies het omgekeerde voor het gefolterde lichaam: het is een climax, een abrupte scheiding in het proces van geritualiseerde pijn.

Tijdens dit hoogtepunt, dit moment van totale en absolute negatie van het slachtoffer door zijn beul, weet Jean Améry een ervaring weer te geven van het onzegbare, van een gevoel dat door het gehele gepijnigde lichaam - bijna prooi van de dood - zindert: 'een gevoel van vreemdheid in de wereld dat door geen enkele latere menselijke communicatie ooit nog kan worden gecompenseerd'.

Hij is het 'fantasmagorische vlees' geworden, het lichaam van het trauma, een 'bewegende en ongelijksoortige lichamelijkheid'. Een lichaam dat zich uit de wereld terugtrekt omwille van een inbreuk die is gepleegd tijdens het folteren: een inbreuk op de huid die als scherm van het Ik-lichaam verondersteld wordt onschendbaar te zijn. Deze inbreuk, dit transgressieve contact met de opperhuid is een aanval op de lichamelijkheid.

Catherine Perret wijst nog op de overeenkomsten tussen Massa en Macht van Elias Canetti (uit het Duits vertaald door Jenny Tuin, Athenaeum-Polak \& Van Gennep, Amsterdam, 1983) en het werk van Jean Améry. De isotopie van de lichamelijkheid (en het geheel van haar in beide essays onderzochte attributen en metonymisch systeem) vormt de kern van hun bespiegelingen. Beide schrijvers spreken over dezelfde ervaring van het freudiaanse Ik, ontwikkeld door de weerspiegelende aanraking (het contact met de eigen huid dat voeling geeft met het eigen Zijn). Volgens Catherine Perret vullen ze elkaar bovendien aan in hun beschrijving van het lichaam: zo is er enerzijds de 'aanrakingsangst' ('het taboe van de aanraking') en anderzijds het 'massakristal', 'deze kern van waaruit de massa aangroeit door louter zelfproducerende energie’.

De huid wordt de plaats van het trauma, de ruimte van de transgressie waarin de beul optreedt in de hoedanigheid van lichaam-folteraar en zijn ritueel begint van zelfbevestiging. De huid is dat wat de binnenwereld scheidt van de buitenwereld; de vernietiging ervan vormt een schending van de binnenwereld die, a contrario het gedeporteerde lichaam, een ruimte vormt waar de vrijheid mogelijk is. Jean Améry vertelt dat zijn identiteit uiteenvalt in een meervoudig 'Ik' (de intellectueel, de communistische verzetsman, de gedeporteerde en de Jood), maar dat er slechts één enkel gefolterd lichaam bestaat. De huid vormt het grensvlak dat met geweld wordt opengebroken door datgene wat dan het verlengstuk wordt van het lichaam van de folteraar: het werktuig, het object van de pijn. Het contact en de permanente transgressie van de huid door de nazi vormen verschillende riten van ontmenselijking, zo legt Perret uit. Bij aankomst in het kamp worden de gedeporteerden ook onmiddellijk gebrandmerkt met een tatoeage op de arm (en met cijfers, die je nog steeds kan zien). 'Améry heeft in de taal datgene gevonden wat van de huid de metonymie maakt van het leven, in tegenstelling tot het overleven.' De ultieme transgressie van de huid van de Ander maakt het vlees tot Woord: door het pijnlijk binnendringen van de huid tijdens het folteren kunnen valse beweringen worden uitgekotst.

Het umstülpen activeert een heel proces van inversie en omkering: tijdens het ritueel wordt de huid niet alleen bewerkt, verscheurd, opengehaald en doorboord, maar ze wordt ook als het ware volledig binnenstebuiten gekeerd, zoals men wild afstroopt. Het slachtoffer voelt zich uit zijn intimiteit verdreven, het 'huist in een lege voering'. De huid omkeren is het lichaam van het slachtoffer omkeren, met andere woorden: het binnenste naar buiten drijven en de intimiteit van de lichamelijkheid schenden. De mens wordt vernietigbaar, zijn huid beschermt zijn lichaam en zijn Ik niet meer; de lichamelijkheid wordt aangevallen en het 'Stück' wordt vlees, vlees van de zelfrealiserende transsubstantiatie. Schaamte vormt dan de ultieme bewustwordingvan het feit dat een grens met geweld werd overschreden, het is het hoogtepunt van de ervaring van het gefolterde lichaam, een proces van zelffoltering. 'Wie eens werd gefolterd, blijft voor altijd gefolterd', meent Améry. In de periode na de deportatie volgt 'de schok van het zich in de steek gelaten voelen', het besef dat de denazificatie eigenlijk pure hypocrisie is. Op dat moment ondergaat de gefolterde een metamorfose. Het 'Wij' wordt onuitspreekbaar, het bestaat niet meer.

'Foltering vormt de kern van een veel uitgebreider ritueel waarvan de huid het middelpunt is, het Lager het toneel, en het Duitse en Europese publiek de onthutste en instemmende toeschouwer.'

Catherine Perret onderzoekt verderop Didier Anzieus concept van het 'Huid-Ik of Huid-Ego' in het licht van Améry's bespiegelingen. Het 'Huid-Ik' lijkt vernietigd tijdens en door het folteren; het Ik is niet alleen verstoken van alle hulp van buitenaf, maar is 
ook zijn intern weerstandsvermogen ontnomen. Zich baserend op een passage uit Améry's tekst, waar het Ik en het Wij uiteindelijk in dezelfde zin naast elkaar staan, besluit Perret dat het 'Huid-Ik' een 'Huid-Wij' wordt. Tweeëntwintig jaar na deze infans-fase ('hij die niet spreekt'), waar de stilte van de pasgeborene na de Shoah in schril contrast staat met de doodskreet van de gefolterde, komt het Wij, door Catherine Perret bestempeld als voorouderlijk en 'resonerend in het Ik', eindelijk weer tevoorschijn om het onzegbare te zeggen. Het Auschwitzproces, dat als algemene kennis geldt van een gemeenschappelijkgoed, doet vervolgens het Ik evolueren naar een 'Huid-Wij': een huid van een gemeenschappelijk goed (Eigentum), 'dat weerstand biedt wanneer het niet meewerkt'.

Hierbij zij vermeld dat het postscriptum van Catherine Perrets essay eindigt met een kafkaiaans beeld uit het slot van Het Proces. De auteur roept de ultieme blik op van een martelaarsfiguur, een verlicht wezen met doorboord hart dat een incarnatie is van Jean Améry's onderzoek naar 'de diepinnerlijke conditie van het slachtoffer'. Een blik die ook de onze is, en deze K. is dan ook onze initiaal... I

Yoann Sarrat

(Vertaling: Macha Snouckaert van Schauburg)

\section{QUAND ULYSSE REVIENT A TRIESTE}

\section{Boris Pahor}

uit het Sloveens naar het Frans vertaald door Jure Kozamernik, Éditions Pierre-Guillaume de Roux, 2013, 329 p.

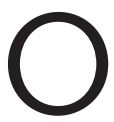

genschijnlijk gebeurt er in deze roman van Boris Pahor niet veel. We schrijven september 1943. De protagonist, een jonge Sloveense soldaat in het Italiaanse leger, heeft net vernomen dat de troepen die onder Italiaans bevel staan, in het Duitse leger moeten dienen om de partizanen te bestrijden. Zoals veel van zijn kameraden heeft hij besloten te deserteren. In het station van Triëst ontsnapt hij aan de Duitsers en daarna loopt hij te voet naar een dorp in de Karst dicht bij zijn geboortedorp. Zal hij zich aansluiten bij de maquisards in de bergen, of bij het verzet dat zich organiseert in Triëst? Op het einde van de roman zien we hem van de heuvels afdalen in de richting van Triëst. Er heeft geen enkele andere handeling plaatsgevonden, behalve dan de reflecties van de hoofdfiguur.

Ondanks deze schijnbare rimpelloosheid bevat de roman historische informatie die tot nadenken stemt. Naar aanleiding van Rudi's ontmoetingen met oude dorpsbewoners halen die laatsten herinneringen op aan het ontstaan van het fascisme en de antifascistische strijd, maar ook aan de Sloveens-nationalistische component: haat tegen Italië (de overheersende macht die neerkijkt op de Sloveense cultuur en het onderricht van de Sloveense taal verbiedt) is aan het antifascisme van sommigen niet vreemd. Verschillende personages verinnerlijken het Italiaanse misprijzen voor de Slovenen, bijvoorbeeld Vida, die een Italiaanse geliefde heeft en niets liever wil dan in de stad te gaan leven. Om zich tegen dat misprijzen af te zetten, steekt de protagonist - of de auteur -, als hij, zoals Odysseus, in zijn geboorteland terug is, de loftrompet over de onherbergzame natuur van de Karst, die mannen en vrouwen vormt die op haar lijken. Voor een Franse lezer roept zulke lof kwalijke reminiscenties op aan het Vichy-regime, maar dat moet worden genuanceerd: ten eerste omdat de 'natuur' van de Karst ten dienste wordt gesteld van de wil tot verzet tegen verdrukking, en vooral omdat er geen tegenstelling is tussen stad en platteland. Hier klinkt geen tegenhanger van de vreselijke slogan 'la terre ne ment pas' (de bodem liegt niet) aangezien de protagonist uiteindelijk besluit in de stad te gaan vechten.

De lezer die meer te weten wil komen over Triëst blijft na de lectuur wat onvoldaan achter, want de stad blijft buiten beeld. De in de titel aangekondigde homerische thematiek is alleen tussen de regels te lezen. En niet elke lezer zal even gevoelig zijn voor de psychologische analyse van het hoofdpersonage, zijn aarzelingen, in de liefde, tussen de frivole Vida en de opstandige Majda, of zelfs voor de bijzonder heftige taferelen die aan het genre van de oorlogsroman raken (de razzia in het station van Triëst, de twee zwijgende onderduikers in de tram). Maar het boek is vooral interessant om de bevestiging van het recht van minderheden om taalkundig en cultureel te bestaan - een bevestiging die absoluut nader moet worden onderzocht, om elke mogelijke verwarring met enige vorm van communautarisme te voorkomen.

Anne Roche

(Vertaling: Katrien Vandenberghe) 


\section{LES ENFANTS DU SILENCE. MÉMOIRES D'ENFANTS CACHÉS}

\author{
Jean-Pierre Guéno
}

Toulouse: Milan, 2013, 87 p.

es Enfants du silence is gebaseerd op een boek dat in 2002 verscheen bij uitgeverij Librio, Paroles d'étoiles. Mémoires d'enfants cachés 1939-1945. Het verhaal werd nu bewerkt voor kinderen van tien tot twaalf jaar. Uit de titel kunnen we afleiden dat het gaat om een verzameling teksten, soms brieven, van Joodse kinderen die tijdens de Tweede Wereldoorlog ondergedoken leefden in Frankrijk. Hun ouders waren gedeporteerd, en keerden in veel gevallen nooit meer terug.

Ondergedoken kinderen zijn in feite kinderen die men met de beste bedoelingen heeft willen beschermen, maar die bijna altijd tegen hun zin en onder dwang werden ondergebracht, weggerukt van hun ouders of afgestaan. Ze hebben de oorlog dan misschien wel overleefd, bij velen onder hen lezen we verdriet en onbegrip dat nooit wegebt. Is dit beter dan de dood, zo vragen een aantal overlevenden zich af, een dood die ze samen hadden kunnen beleven met hun ouders, broers en zussen? Ze worstelen een leven lang met die vraag.

Er rijst een ander probleem: zijn deze teksten, geschreven door volwassenen die als kind zijn ondergedoken, wel geschikt voor een publiek van tien- tot twaalfarigen, zoals Jean-Pierre Guéno beweert in zijn voorwoord (op de flap lezen we zelfs een optimistische 'vanaf 10-11jaar')? Lezers met een beperkte kennis over de anti-Joodse maatregelen en vervolgingen worden verwezen naar een verklarende woordenlijst, maar we moeten toch vaststellen dat de literaire getuigenissen met hun talrijke allusies te gelaagd zijn voor de vooropgestelde leeftijd. De teksten zijn niet in de eerste plaats voor kinderen bestemd. Een mogelijkheid zou zijn om de teksten in de klas te lezen onder begeleiding van een leerkracht. Echter, dan houden we nog geen rekening met de gruwelijke ervaringen die in het boek staan beschreven en die jonge kinderen van hun stuk kunnen brengen.

Als volwassene en groot liefhebber van kinderboeken vond ik de verhalen wél erg pakkend. Ik moest denken aan Theodor Herzl die in Der Judenstaat schrijft dat 'na een korte periode van verdraagzaamheid de vijandigheid tegenover de Joden toch altijd weer opflakkert'. Als volwassene dus, moest ik even slikken bij het fragment van de boerin uit Vercors. Twee jaar lang verborg ze een Joods kind in haar huis, maar toen ze aan het kleintje opgewonden vertelde dat Frankrijk eindelijk bevrijd was, staarde het kind haar stomverbaasd aan. De brave vrouw riep toen uit: 'Die Joden! Ze zijn waarachtig nooit tevreden!'

'Na een korte periode van verdraagzaamheid...' Had Herzl gelijk?

Jean-Pierre Pisetta

(Vertaling: Anneleen Spiessens)

$\bullet$

\section{LE MYTHE DE LA TRANSITION PACIFIQUE. VIOLENCE ET POLITIQUE EN ESPAGNE (1975-1982)}

\author{
Sophie Baby \\ Madrid: Casa de Velázquez, 2012, 527 p.
}

D it boek maakt eerst en vooral indruk door zijn omvang: 527 bladzijden, waarvan 440 dichtbedrukt. De bibliografie is indrukwekkend en de documenten in de bijlage waardevol. Het gaat hier om de uitgegeven versie van een proefschrift met ongeveer de omvang van het doctorat d'État. Zoals de auteur in haar dankwoord schrijft, is de tekst het resultaat van meer dan vijftien jaar werk: ongeveer tien jaar voor het eigenlijke proefschrift dat ze in 2006 aan de universiteit Paris 1 Panthéon-Sorbonne heeft verdedigd, en zes jaar voor het redactiewerk aan het boek.

De titel geeft het al aan: het onderzoek gaat over de politieke overgang in Spanje (kortweg la Transición) tussen de dood van dictator Francisco Franco Bahamonde in november 1975 en het jaar 1982, toen na verkiezingen in oktober de socialisten aan de macht kwamen. In die zeven jaar is er na een aftastende periode een democratische Grondwet geschreven, goedgekeurd en bij referendum (6 december 1978) aangenomen. Dat gebeurde in het kadervan de monarchie onder leiding van Juan Carlos I, de opvolger van Franco. De machtsgreep van de socialisten aan het eind van 
de periode vestigde het nieuwe regime: voor het eerst werd het in het nieuwe democratische kader mogelijk dat er een andere meerderheid aan de macht kwam. Eind goed al goed.

Tot aan het eind van de jaren negentig is het overheersende discours over deze periode in de geschiedenis van Spanje dat de politieke overgang in het land op een ideale wijze is verlopen, op basis van een consensus waardoor de politieke actoren het over de essentie eens konden worden (de vestiging van een democratisch regime), en met een aantal concessies door de diverse betrokkenen. Een modeltransitie dus, die voor veel landen als een referentie fungeert bij het beheren van het einde van een dictatuur en wat daarna komt: de Latijns-Amerikaanse landen in de jaren tachtig en vervolgens de landen van Oost-Europa na de Val van de Berlijnse Muur. Sophie Baby heeft het echter over een 'mythe', een woord dat André Bazzana in dit verband als eerste heeft gebruikt. Anders gezegd: een discours dat uitentreuren wordt herhaald en uiteindelijk de status van 'waarheid' bereikt, ten koste van de historische werkelijkheid.

'De mythe van de vreedzame overgang': dat is precies wat het onderzoek van Sophie Baby probeert te deconstrueren. Bij de verschijning van haar boek in 2012 was zij niet de eerste en dus ook niet de enige die dit deed. Fascinerend aan haar werk is de zeer overtuigende wijze van bewijsvoering en de ernst waarmee ze te werk gaat. Wat le mythe de la Transition pacifique écht beoogt, is het onder de mat schuiven van het geweld. De mythe heeft een duidelijke politieke functie omdat ze de kaart speelt van de elites die destijds voor de overgang hebben gezorgd, maar ze heeft ook een maatschappelijke functie. Sophie Baby doet precies het omgekeerde: zij haalt het politieke geweld dat in deze periode plaatsvond naar boven. In haar werk legt ze het verzonken deel van een gigantische ijsberg bloot. Methodisch, geduldig en moedig heeft de auteur wat zij samenbrengt onder de noemer 'vormen van politiek geweld bij de overgang' (15) geïnventariseerd, gerangschikt en geanalyseerd. Ze verzamelde een indrukwekkend - en door zijn omvang onuitgegeven - corpus van ongeveer 3200 gewelddadige voorvallen (met meer dan 700 doden) in de periode tussen de dood van Franco en het einde van het jaar 1982. Volgens de auteur 'vormt dit slechts een minimum' (43). Het belang van dit corpus is ook dat het zich niet beperkt tot de 'klassieke' uitdrukking van politiek geweld (aanslagen), maar dat het ook acties in veel gedaanten omvat, die de hele periode door een klimaat van geweld creëerden (bedreigingen, rellen, protestacties, onrust in de publieke ruimte, ...). Tot slot: Baby focust niet alleen op geweld gepleegd door vertegenwoordigers van de Staat, maar ook door de oppositie. Niets of niemand leek de spiraal te kunnen stoppen. Het canonieke beeld over het geweld, dat in deze periode ofwel als een sporadisch voorkomend fenomeen wordt bestempeld (de mislukte staatsgreep van luitenant-kolonel Tejero op 23 februari 1981), ofwel als een 'marginale aberratie die de samenhang van de rest van Spanje juist nog meer luister bezorgt' (6), is hier veraf.

Na een inleidend stuk dat de contouren van de 'vormen van politiek geweld tijdens de overgang' schetst en een stevig epistemologisch en methodologisch kader aanreikt, bevat het werk twee grote delen. Daarin onderzoekt de auteur achtereenvolgens 'De cyclus van het protestgeweld' (61-234) en 'De Staat en het geweld' (235-420). Het volume van de onderzochte archieven is indrukwekkend, net zoals de vele bijzonder sprekende overzichtstabellen die de waargenomen fenomenen op een heldere wijze visualiseren. De helderheid van de bewijsvoering en de correcte analyses maken de lectuur van deze summa ongemeen boeiend. En hoewel het voorwerp van de studie op het eerste gezicht tot een voltooid verleden behoort, doet dit werk over de overgang in Spanje bij de lezer ook eigentijdse politieke belletjes rinkelen. De grenzen van de 'pacifistische mythe van de transitie' komen er duidelijk uit naar voren. De meeste herinneringen aan het politieke geweld van die periode zijn, zoals Sophie Baby in haar besluit vermeldt, 'uit het collectieve geheugen verdwenen, vermorzeld onder het gewicht van de institutionele mythe' (438). Toch blijft ook het gewicht van een onvoltooide transitie, die door dingen te verduisteren nog niet echt in het reine is gekomen met het Franco-regime, meer dan ooit aanwezig in een land waar de demonen van het verleden voortdurend de kop blijven opsteken. Dat bevestigt de actualiteit van het besluit van de auteur: 'Het geweld bevindt zich, ondanks de inspanningen die worden geleverd om het uit de democratische ruimte te houden, nog steeds in het hart van de politieke activiteiten van het hedendaagse Spanje.' (440)

Nancy Berthier (Vertaling: Patrick De Rynck) 


\section{RWANDA. RACISME ET GÉNOCIDE. L'IDÉOLOGIE HAMITIQUE}

\author{
Jean-Pierre Chrétien \& Marcel Kabanda
}

Parijs: Belin, 2013, 379 p.

' $\mathrm{H}$ et is niet onze bedoeling om onze gal te spuien, laat staan om dwaze uitspraken te doen', verzekeren historici Jean-Pierre Chrétien en Marcel Kabanda in de inleiding van hun boek. Maar was het echt nodig om meteen het werk neer te sabelen van mensen 'die geïnteresseerd zijn in de regio zonder er ooit te zijn geweest, zonder ooit de lucht op de heuvels te hebben ingeademd, zonder ooit op een erf te zijn ontvangen...?' De lijst van tekortkomingen van deze zelfverklaarde 'opiniemakers' is volledig naast de kwestie.

Nochtans is de rest van dit essay uitzonderlijkgoed geschreven en minutieus uitgewerkt. Een genocide komt er niet van de ene dag op de andere, het is ook geen wilde ingeving om een vliegtuigcrash te wreken, zelfs al zou die het werk zijn van een gewapende groep mensen die behoort tot een deel van de bevolking datje hartsgrondig haat. Het is allereerst die haat jegens een bepaalde bevolkingsgroep, een haat die vervolgens tot instrument wordt gemaakt van een politieke beweging, die de katalysator is geweest van de slachtpartijen. Het boek van Chrétien en Kabanda is opmerkelijk omdat de auteurs gaan graven naar de wortels van die afkeer, en daarvoor teruggrijpen naar verrassende, eeuwenoude theorieën.

De hamitische of chamitische ideologie, die aan de oorsprong zou liggen van het Rwandese racisme, ontstond in het midden van de negentiende eeuw. De naam verwijst naar Cham, die door zijn vader Noach werd verstoten omdat hij geen respect toonde. Volgens aanhangers van deze theorie waren de Hamieten 'herders van Kaukasische afkomst. Ze kwamen aan in golven, beter gewapend en bijdehanter dan de negerboeren met hun donkere huidskleur' (alle citaten vonden de auteurs in waarnemingen of kritische theorieën). Honderden of misschien wel duizenden jaren voor de blanken er voet aan wal zetten, zou Zwart-Afrika dus al gekoloniseerd zijn geweest door 'superieure rassen uit Azië' die verschilden van de 'gewone negers', die 'duizenden primitieve gorilla's die daar met z'n allen zitten te verkommeren op een grond die nochtans vol zit met natuurlijke rijkdommen'.

Hamieten of Chamieten, 'een verloren stam van Israël', afstammelingen van Cham die door Noach werd afgewezen: meer was er niet nodig om deze 'sympathieke, rijzige mensen met fijne gelaatstrekken' om te dopen tot 'Afrikaanse Joden' (daarom dachten de auteurs aan de titel 'Van Jood tot Tutsi').

De fysieke aantrekkingskracht en de schoonheid van deze zwarte 'nieuwelingen' - en daarin waren ze het tegenbeeld van de 'autochtone' negers - spreekt de blanke ontdekkingsreizigers meteen aan. 'We zagen in een oogopslag', zo schrijft John Hamming Speke in 1861, 'dat de mensen die we hier tegenkwamen heel anders waren dan die onbehouwen inboorlingen uit de naburige districten.' Dertig jaar later voegt Stanley daaraan toe: 'De mooie herders zorgen voor hun kuddes terwijl de negers met hun platte neuzen en pikzwarte huid met hun spade inhakken op de aarde.'

Dit statige voorkomen heeft echter een nadeel. Hoewel ze in eerste instantie geadoreerd worden door de blanken, die zichzelf herkennen in deze wezens met gelaatstrekken die gebeeldhouwd konden zijn 'door Praxiteles zelf', laten ze zich niet gemakkelijk om de tuin leiden en zijn ze soms tegendraads. Door die houding, en dat merken de auteurs terecht op, krijgen ze bij de kolonisten al gauw de reputatie van bedriegers. De Hamieten, 'superieure klasse onder de Negers', wekken tegelijkertijd fascinatie en wantrouwen op. Hun 'superioriteit', zoals die wordt gepercipieerd, getheoretiseerd en zelfs verjoodsd door de blanken, weerspiegelt zich in de maatschappelijke verhoudingen in die contreien, tot de perceptie uiteindelijk doorgaat voor een feit.

Dat zijn de ingrediënten voor de genocide, die nog een kleine eeuw kunnen sudderen voordat de zogezegde Hamieten (de wetenschappelijke benaming voor de Tutsi's, zo weten we nu) effectief zullen worden uitgeroeid.

De Kerk neemt het daarna over van de ontdekkingsreizigers en de ideologen. De Tutsi's worden als eersten gekerstend en zijn geprivilegieerde bemiddelaars tussen de blanke machthebbers en het Rwandese volk, dat nochtans grotendeels uit Hutu's bestaat.

Enkele decennialater, in 1959, aan de vooravond van de onafhankelijkheid, overhandigen Hutu's een 'Nota over het maatschappelijke aspect van het inheemse rassenprobleem in Rwanda' aan de koloniale autoriteiten. 
De auteurs van de nota stellen een dubbele overheersing aan de kaak: die van de 'Hamieten' en die van de 'Europeanen', waarbij de laatsten bovendien diezelfde 'Hamieten' als ‘kanaal' gebruiken.

Omdat in Congo ondertussen een vurige ontvoogdingsstrijd aan de gang is, waarvan de leiders verdacht worden banden te hebben met de 'bolsjewieken', verandert de Kerk van mening. Ze steunt de grieven van de Hutu's, tot groot ongenoegen van de Tutsi's die steeds een voorkeursbehandeling hebben genoten.

De spanningen lopen hoog op en monden uit in confrontaties tussen Hutu's en Tutsi's op Allerheiligen 1959. Tutsi's worden voor het eerst massaal uitgemoord en zullen na de 'pacificatie' door de Belgen ontzet worden uit de macht.

In 1962 roept Grégoire Kayibanda de eerste republiek uit. De Hutu's, die de meerderheid uitmaken van de bevolking, zullen nu dertig jaar lang ook in gelijke verhouding vertegenwoordigd zijn in de verschillende staatsinstellingen. Onder Juvénal Habyarimana's tweede republiek wordt de Rwandese samenleving, zoals die werd uitgedacht en ingericht door de blanken, verder geracialiseerd: de Tutsi is nu definitief, unaniem en zelfs historisch, een indringer.

In fijne toetsen schilderen Chrétien en Kabando het portret van een genocide die onderhuids sluimert. Wanneer het dan zo ver is en de genocide in al haar gruwel losbarst, krijgen we een déjà-vu-gevoel: de zuivering van Rwanda door de Hutu Power vertoont opvallende gelijkenissen met de zuiveringen zoals die tijdens de Tweede Wereldoorlog in het oosten werden uitgevoerd door de Einsatzgruppen. De (systematische) methode is dezelfde en de lokale (gedecentraliseerde) bevolking wordt er eveneens in betrokken, terwijl die waarschijnlijk nooit had deelgenomen als ze niet 'van buitenaf' was opgejaagd en als het niet zo eenvoudig was geweest om de vijand (eenzijdig) te identificeren op basis van ras. 'Judenfrei', riepen de nazi's wanneer ze dachten alle Joden uit een regio te hebben vermoord; 'Tutsifrei', dat was kennelijk de ambitie van de voormalige onderdanen van Duitsland (Rwanda was een Duitse kolonie tussen 1890 en 1916).

Het boek gaat jammer genoeg niet voldoende in op de vergeldingsacties waarvan de Hutu's achteraf slachtoffer zijn geworden, en dan in het bijzonder diegenen die naar Congo waren gevlucht en lang niet allemaal betrokken waren bij de genocide. Ook zijn er talrijke Hutu's die vóór 1994 de macht wilden deelden met de Tutsi's en daarom tijdens de genocide hetzelfde lot ondergingen. De auteurs brengen dat feit in herinnering aan het begin van hoofdstuk 9, 'Le génocide (avril-juillet 1994): les mots et les choses': 'Werden geviseerd: de Tutsi's in hun geheel en de Hutu's in de oppositie die werden gezien als hun "handlangers". (213) De slachtpartijen op Hutu's in de nasleep van de genocide van de Tutsi's kunnen echter niet, zoals de auteurs benadrukken, beschouwd worden als een tweede genocide.

Tot slot volstaat het niet om de complottheorieën over de Amerikanen en de Tutsi's in het belachelijke te trekken om het optreden van de Verenigde Staten voor of na de genocide te bekritiseren. Denk maar aan de rol die het land speelde in de moord op Patrice Lumumba en in de machtsgreep van Mobutu in buurland Congo: hoe konden de Amerikanen zich niét aantrekken wat er in Rwanda gebeurde? Het lijkt erop dat de Nieuwe Wereld hier de fakkel overnam van de katholieke Kerk, die in de jaren voor de onafhankelijkheid aan de zijde van de Hutu's de strijd aanbond met de zogenaamde 'linkse' Tutsi's.

Toch is dit een voortreffelijk boek, dat helder aantoont dat racisme - of liever, de angst voor wie ons vreemd is - des mensen is en dat een wetenschappelijk discours, mits geduld en volharding, dieblik op de ander kan betonneren in maatschappelijke verhoudingen. De nazi's slaagden daarin met de Joden; de Hutu's met de Tutsi's.

Jean-Pierre Pisetta

(Vertaling: Anneleen Spiessens) 